\title{
B-SMART: A university-industry teaching innovation project
}

\section{Dolors Gil-Doménech, Jasmina Berbegal-Mirabent, Marta Mas-Machuca}

Department of Economy and Business Organisation, Universitat Internacional de Catalunya, Spain.

\begin{abstract}
The present work aims at presenting a teaching innovation project, the BSMART, which has been implemented at UIC Barcelona in the academic year 2018/19. Conceived as a project to respond to social demands, the B-SMART project aims at creating a collaborative environment and at strengthening the ties between companies (mainly targeted to SMEs, start-ups and NGOs) and the university. To do so, students work on real challenges or projects posed by companies. This approach helps students to better understand the theoretical concepts taught in class as well as to boost soft skills that will be required in their daily practice. In turn, companies gain access to new talent (students), fresh ideas, and the knowledge and infrastructures available at the university. In this study we explain the project and pay special attention to the first two projects solved through the B-SMART project. We use design thinking as the teaching method. Preliminary results show that both students and companies benefit from this experience.
\end{abstract}

Keywords: University-industry collaboration; project-based learning; design thinking; skills acquisition. 


\section{Introduction}

B-SMART (which stands for Be Socially-engaged, Motivated, Agile, Resolute and Talented) is a project developed by a group of lecturers from the Faculty of Economics and Social Sciences at the Universitat Internacional de Catalunya (UIC Barcelona). It is funded by the Fundació Puig and the Aula d'Innovació Docent UIC Barcelona. The project aims at creating a collaborative environment and at strengthening the ties between companies (mainly targeted to SMEs, start-ups and NGOs) and the university. In this way, the $B$ SMART project follows the line indicated by several academic studies, which claim the need to link university learning to professional reality, making the educational process a professional and personal experience (Bennett, Dunne, \& Carre, 1999). These calls for a greater connection between higher education institutions and industry have led to a paradigm shift in teaching methodologies, streamlining content while promoting its application in a real environment and boosting the development of students' skills (McCabe, \& O’Connor, 2014).

In this context, the idea behind the B-SMART project is to have students working on realworld projects (real challenges posed by companies) in order to help them better understand the theoretical concepts taught in class (hard skills) as well as to enhance some soft skills (e.g. entrepreneurship, creativity and innovation, critical thinking and team working), thus facilitating a lifelong learning (Star, \& Hammer, 2008). In turn, companies gain access to new talent (students), fresh ideas, and the knowledge and infrastructures available at the university.

These projects or challenges are introduced in the syllabus of different courses in the Bachelor's Degree in Business Administration, according to the topic to be developed (e.g. human resouces, operations management, marketing, etc.). Such projects are conceived as compulsory activities, meaning that in order to pass a subject students should work on these projects. The solution to the project/challenge is evaluated both by the instructor of the course and the company. Each project might have a different length (according to the complexity of the problem to be solved).

The original value of the B-SMART project can be summarised in the following points:

- It promotes university-industry collaborations.

- It is based on real projects.

- It includes a social aspect, helping SMEs, NGOs and start-ups.

- It is a multidisciplinary and transversal project, involving several subjects and lecturers from different disciplines.

- It is transferable to other programs. 
Therefore, the B-SMART project is expected to bring the advantages listed in Table 1:

Table 1. Advantages of the B-SMART project

\section{Actors}

Companies (SMEs and start-ups) and NGOs

Students

Lecturers

Facilitators of the project (Fundació Puig and Aula d’Innovació Docent UIC Barcelona)

\section{Advantages}

Get support to respond to existing problems or develop new lines of products, hire new talent, and get free access to qualified workforce (students and teaching staff)

Apply the concepts taught in class in real cases, learn how companies operate and evolve, work with professionals, and develop soft skills

Obtain real content for their classes, receive training in active learning methodologies, and develop skills

Gain visibility and position themselves as facilitators of university-industry collaborations

Own source (2018).

\section{Teaching method}

For the development of the B-SMART project, and being coherent with its innovative spirit, its implementation in the classroom is based on an active learning methodology that provides dynamism, facilitates the generation of ideas and is appropriate for the university environment: design thinking.

In the current business environment, design thinking is emerging as one of the most useful tools to promote creativity, innovation and entrepreneurship. Specifically, this methodology focuses on people as developers of innovation. In this sense, it offers a lens through which to observe challenges, detect needs and, ultimately, propose solutions. In other words, the approach offered by design thinking uses the sensibility of the designer and its method of solving problems to meet people's needs in a technologically feasible and commercially viable way. This methodology has been proved to facilitate the development of ideas based on the real needs of the users, while allow companies to create products capable of playing an increasingly prominent role in the market and its competitive environment. 


\section{Projects}

\subsection{SaóPrat Association}

The company

SaóPrat Association is a socio-educational, non-profit and declared of public utility entity, founded in 2004 in el Prat de Llobregat (Barcelona). Its main aim is to respond to the educational and social needs of the children, adolescents and youth in need in the area.

\section{The challenge}

SaóPrat requires a Human Resources consulting job. They have defined an organisation chart with different jobs. Now, they need someone that helps them to perfrom an analysis of the competences associated to each job position.

This case was analysed in the course of Human Resources ( $3^{\text {rd }}$ year of the Bachelor's Degree in Business Administration at UIC Barcelona) during the first semester of the academic year 2018/19. It received the support of both the director of SaóPrat and the coordinator of the Area of Funding of Resources. The involvement of the entity was key to ensure the proper deployment of the mission of the entity (i.e. to accompany young people, children and their families).

\section{$\underline{\text { Results obtained }}$}

Students had to prepare a report with the following information:

- Catalogue of competencies according to the needs of SaóPrat Association.

- $\quad$ List of competences (reduce it to 15 transversal competences).

- Definition of each competence.

For each job position, students had to propose 4-5 transversal competences. In order to assess the resolution of the challenge, creativity, the justification of the choice of competences and the methodology followed were considered. The best reports were presented to the heads of the Association.

\subsection{La Casa de Carlota}

The company

La Casa de Carlota is a design agency founded in 2013 in Barcelona, that includes people with intellectual disabilities in its creative team. For the past five years the company has gained a strong national and international client base and has demonstrated a positive economic evolution. 


\section{The challenge}

La Casa de Carlota is facing the challenge of how to replicate, scale, and expand the business model to other countries and sectors. As true social entrepreneurs, they are not only inerested in economic scalability, but also in provoking a systemic social change, which may allow people with intellectual disabilities to integrate into society and bring value to it thanks to their unique abilities, such as lateral thinking, audacity, and empathy.

This case was analysed in the courses of Social Entrepreneurship (2 ${ }^{\text {nd }}$ year of the Bachelor's Degree in Business Administration at UIC Barcelona) and Entrepreneurship (4 $4^{\text {th }}$ year), during the first semester of the academic year 2018/19.

\section{$\underline{\text { Results obtained }}$}

Students were challenged to open their minds and propose ideas on how to replicate the business model of La Casa de Carlota in a sustainable way (both economically and socially). Each group presented their ideas in the form of a report and an elevated pitch to the board of directors of the company. Students' proposals were very positively valued.

From the students' viewpoint, they really enjoyed solving the challenge and acknowledged that this activity helped them to explore their ability to innovate and to discover that by working in teams, superior ideas can be reached. Certainly, the methodology used, which presupposes working in small teams with a strict "do not judge" rule, helped them to be bolder in their ideas and enhanced the participation of all of them.

\section{Conclusion}

In this study we have reported the experience of the B-SMART project. This is a 2-year project that has started this academic course (2018/19). With this project we expect to help university students to practise their skills and apply their knowledge to solve real business problems.. In order to show how the project develops, two examples have been detailed.

So far, the results obtained are encouraging. Both companies and students find the project useful and worth. Next steps involve spreading the geographical scope of the project, involving different universities and companies from other countries. That is, having students from university A located in country $\mathrm{X}$ working together with students from university B located in country $\mathrm{Y}$, all of them solving a project from company $\mathrm{C}$ located in country Z. 


\section{References}

Bennett, N., Dunne E., \& Carre, C. (1999). Paterns of core and generic skills provision in higher education. Higher Education, 37, 71-93.

McCabe, A., \& O’Connor, U. (2014). Student-centred learning: The role and responsibility of the lecturer. Teaching in Higher Education, 19(4), 350-359.

Star, C., \& Hammer, S. (2008). Teaching generic skills: Eroding the higher purpose of universities, or an opportunity for renewal? Oxford Review of Education, 34(2), 237251. 